\title{
Proceeding Paper \\ Change the Story, Learning to Make a Difference in Climate Crisis ${ }^{\dagger}$
}

\author{
Luca Baglivo and Daniela Conti *
}

Citation: Baglivo, L.; Conti, D. Change the Story, Learning to Make a Difference in Climate Crisis. Environ.

Sci. Proc. 2022, 14, 4. https://doi.org/ 10.3390/environsciproc2022014004

Academic Editors: Andreas Ch. Hadjichambis, Pedro Reis, Marie-Christine Knippels, Audrone Telesiene, Daphne Goldman, Demetra Paraskeva-Hadjichambi, Jan Cincera and Kateřina Jančaříková

Published: 1 March 2022

Publisher's Note: MDPI stays neutral with regard to jurisdictional claims in published maps and institutional affiliations.

Copyright: (C) 2022 by the authors. Licensee MDPI, Basel, Switzerland. This article is an open access article distributed under the terms and conditions of the Creative Commons Attribution (CC BY) license (https:// creativecommons.org/licenses/by/ $4.0 /)$.
Centre for Environmental Research, Documentation and Education CREDA, 20900 Monza, Italy; luca.baglivo@creda.it

* Correspondence: daniela.conti@creda.it

† Presented at the 2nd International Conference of International Researchers of the Education for Environmental Citizenship 2022, 10-11 March 2022. Available online: https:/ / enec-cost.eu/ireec22/.

Abstract: We describe the results of the Italian piloting of Change the Story, a cross-European project that takes an innovative look at climate and citizenship education. The project developed resources to support teachers and pupils in creating digital narratives about the kind of world they want as a response to the climate crisis, with the aim of both improving scientific enquiry and developing citizenship competences to actively contribute to building a climate-neutral society.

Keywords: climate education; environmental citizenship; action competences; sustainability inquire learning; digital storytelling; place-based education

\section{Introduction}

Engaging young people to become change-makers [1] in the large challenges of the climate and sustainability crisis requires new educational approaches to empower students to make decisions and move towards social change, going beyond fostering students' environmental awareness. Education has been recognised as a critical element to deliver sustainable development [2,3] (UNESCO, 2012; UNESCO, 2014) and educative institutions need to delineate pedagogies to promote the potentialities embraced by sustainability challenges to effectively work on students' action and citizenship competences [4] allowing them to be ready to build a better world for all.

In this context, a group of six European education organizations have explored this issue within the project named Change the Story, co-funded by the Erasmus+ programme of the European Union [5], which has focused on digital storytelling as a coherent frame for students' research into and exploration of climate change to empower them to become agents of change with their friends and community.

\section{Research Design and Methodology}

We worked together with 10 teachers and 60 students during the 2020-2021 school year. Action research [6] was set up to outline the educational foundation for intentional environmental and civic climate action within primary education settings.

Firstly, a flow of learning grounded in the inquiry-based approach $[7,8]$, which also includes the local community as an educational resource [9] and a creative approach of digital storytelling [10], was established to guide the co-design and the evaluation of curriculum units, together with the assessment tools used to chart the competence development progress made by students, as described in Table 1.

A framework document, gathered from the widely used framework TPACK [11], has been outlined, which lays out the principles and thinking behind the design of the Change the Story learning units. 
Table 1. Dimension of the competences considered in Change the Story.

\begin{tabular}{|c|c|c|}
\hline Competence & $\begin{array}{l}\text { Competence } \\
\text { Description }\end{array}$ & Indicators \\
\hline $\begin{array}{l}\text { Pupils can find, evaluate } \\
\text { and use information about } \\
\text { past, present and future } \\
\text { climate change }\end{array}$ & $\begin{array}{l}\text { Search, organize and } \\
\text { use information for } \\
\text { specific purposes }\end{array}$ & $\begin{array}{l}\text { Search information from a variety of } \\
\text { digital or non-digital sources } \\
\text { Evaluate authenticity, reliability, or } \\
\text { validity to interpret or use information } \\
\text { Use and share information effectively } \\
\text { and ethically }\end{array}$ \\
\hline $\begin{array}{l}\text { Pupils can think in a } \\
\text { critical way to show how } \\
\text { change in people's } \\
\text { practices is possible }\end{array}$ & $\begin{array}{c}\text { Ask, enquire, } \\
\text { synthesize, evaluate }\end{array}$ & $\begin{array}{c}\text { Questioning and analyzing evidence of } \\
\text { climate change } \\
\text { Extend understanding of climate change } \\
\text { Apply scientific approach to analyze, } \\
\text { evaluate, and take actions on climate } \\
\text { change }\end{array}$ \\
\hline $\begin{array}{l}\text { Pupils can work with } \\
\text { others to develop their } \\
\text { digital story about the } \\
\text { climate crisis. }\end{array}$ & $\begin{array}{c}\text { Participate, collaborate } \\
\text { data }\end{array}$ & $\begin{array}{c}\text { Share responsibility } \\
\text { Value the contributions of others } \\
\text { Demonstrate sensitivity to other audience } \\
\text { or contexts }\end{array}$ \\
\hline $\begin{array}{l}\text { Pupils can create contents } \\
\text { about and for the planet, } \\
\text { living organisms and } \\
\text { people, including } \\
\text { themselves }\end{array}$ & $\begin{array}{l}\text { Apply ideas in new } \\
\text { ways, create } \\
\text { something of value, } \\
\text { elaborate data }\end{array}$ & $\begin{array}{l}\text { Create new narratives for the future } \\
\text { within digital and not-digital contexts }\end{array}$ \\
\hline $\begin{array}{l}\text { Pupils can communicate } \\
\text { with others }\end{array}$ & $\begin{array}{l}\text { Share, exchange ideas } \\
\text { considering impact, } \\
\text { respect for others }\end{array}$ & $\begin{array}{c}\text { Produce and share coherent and cohesive } \\
\text { contents on climate change through } \\
\text { digital or non-digital, oral, written, or } \\
\text { non-verbal means. }\end{array}$ \\
\hline $\begin{array}{l}\text { Take responsibility on how } \\
\text { to tackle the climate crisis }\end{array}$ & $\begin{array}{l}\text { Acknowledge and } \\
\text { accept the choices } \\
\text { made }\end{array}$ & $\begin{array}{l}\text { Demonstrate responsible citizenship } \\
\text { through actions that contribute to } \\
\text { sustainable communities. } \\
\text { Evaluate the impact of decisions or } \\
\text { actions on the dignity and well-being of } \\
\text { individuals or communities }\end{array}$ \\
\hline
\end{tabular}

\section{Findings}

Pupils showed progression in climate literacy and the development of both sustainability and digital competencies, as shown in Figure 1. Students built an interdisciplinary approach to climate crisis and were able to make connections and interrelations between facts, data and climate data visualization. The communication phase, carried out through digital storytelling, triggered the motivation to re-elaborate findings and to create an effective call to action for schoolmates and friends. In particular, the process of creating digital stories (for some examples, see Figure 2) was found to actively enable and engage pupils in:

- Researching and understanding the basic physical science basis behind climate change;

- Searching for causes, effects and solutions;

- Having real-world experiences and observing their environment and society regarding climate change;

- Reflecting and making connections within the frames of time (past, present, future) and dimension (the self, the community, the global society).

- Expressing their ideas on climate crisis and on what they want to change in order to build a climate-neutral society.

- Competences development data were collected with self-reflection tools such as the one described in Table 2. The results are summarized in Figure 3. 


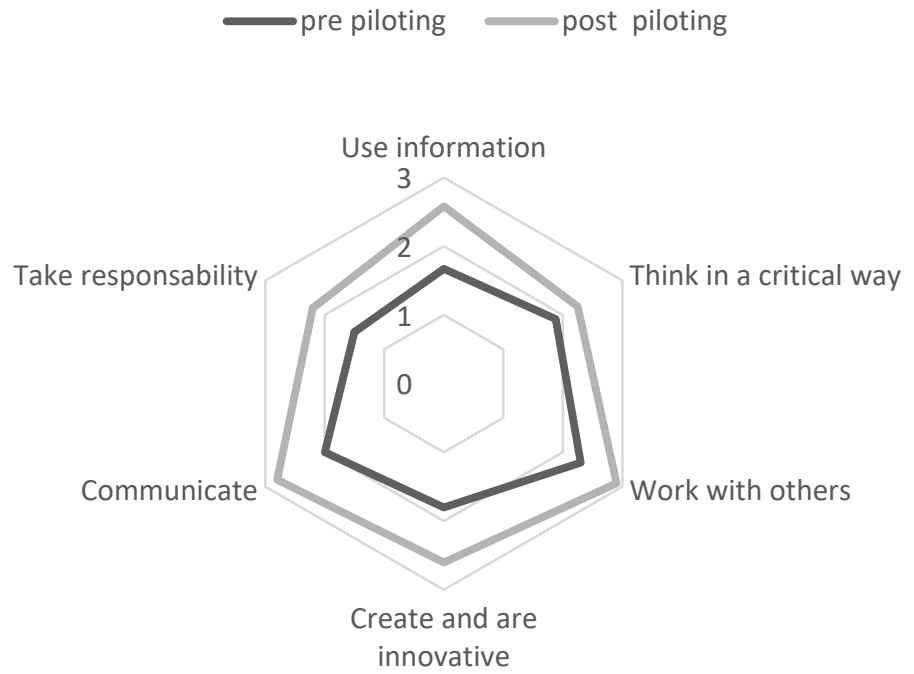

Figure 1. Results of teachers pre- and post-piloting competences assessment.

Table 2. Change the Story aimed to support pupils in developing and self-reflecting on their own digital stories about the climate crisis. Since the goal is that pupils prepare and communicate stories that are powerful to them, formative assessment tools supported content knowledge and competences development process. This example of a self-reflection tool was used throughout the process of producing a digital story about the climate crisis.

\begin{tabular}{|c|c|c|c|}
\hline I Can & Starting & On the Way & Indipendent \\
\hline $\begin{array}{l}\text { Inspiring others through a } \\
\text { digital story about the climate } \\
\text { crisis }\end{array}$ & $\begin{array}{l}\text { I still need to learn about some } \\
\text { digital tools that help me to } \\
\text { share my story with others. }\end{array}$ & $\begin{array}{l}\text { I have learned about some } \\
\text { digital tools. Now I need to } \\
\text { find out how they can help me } \\
\text { to share my story with others. }\end{array}$ & $\begin{array}{l}\text { I can use digital tools to share } \\
\text { and communicate effectively } \\
\text { to different audiences. }\end{array}$ \\
\hline $\begin{array}{l}\text { Investigating the past and } \\
\text { present }\end{array}$ & $\begin{array}{l}\text { I am still learning about how } \\
\text { to investigate and understand } \\
\text { changes in the past, and how } \\
\text { this influences the present } \\
\text { climate. }\end{array}$ & $\begin{array}{l}\text { I am investigating changes in } \\
\text { the past, to find out how this } \\
\text { influences the present climate. }\end{array}$ & $\begin{array}{c}\text { I can investigate and } \\
\text { understand changes in the } \\
\text { past in relation to the present } \\
\text { climate situation. }\end{array}$ \\
\hline $\begin{array}{l}\text { Sharing of my ideas for } \\
\text { making changes }\end{array}$ & $\begin{array}{l}\text { I still need to learn about how } \\
\text { I can be part of making change }\end{array}$ & $\begin{array}{c}\text { I am starting to learn about } \\
\text { how to be part of making } \\
\text { change. }\end{array}$ & $\begin{array}{l}\text { I can be part of making } \\
\text { change. }\end{array}$ \\
\hline $\begin{array}{l}\text { Changing things in the } \\
\text { present for climate crisis }\end{array}$ & $\begin{array}{l}\text { I still need to learn how } \\
\text { people, including myself can } \\
\text { make changes in the present. }\end{array}$ & $\begin{array}{l}\text { I'm learning how people } \\
\text { including myself can make a } \\
\text { change in the present. }\end{array}$ & $\begin{array}{c}\text { I'm aware ofhow people are } \\
\text { influencing and can make } \\
\text { changes. }\end{array}$ \\
\hline Working with others & $\begin{array}{l}\text { I still need to find out how I } \\
\text { can work with others (pupils, } \\
\text { teachers, parents, friends or } \\
\text { other experts) to create a new } \\
\text { story which tackles the } \\
\text { climate crisis. }\end{array}$ & $\begin{array}{l}\text { I am starting to find out how I } \\
\text { can work with others to create } \\
\text { a new story about what we } \\
\text { can do about the future } \\
\text { climate. }\end{array}$ & $\begin{array}{l}\text { I can work with others to } \\
\text { create a new story which } \\
\text { tackles the climate crisis. }\end{array}$ \\
\hline
\end{tabular}




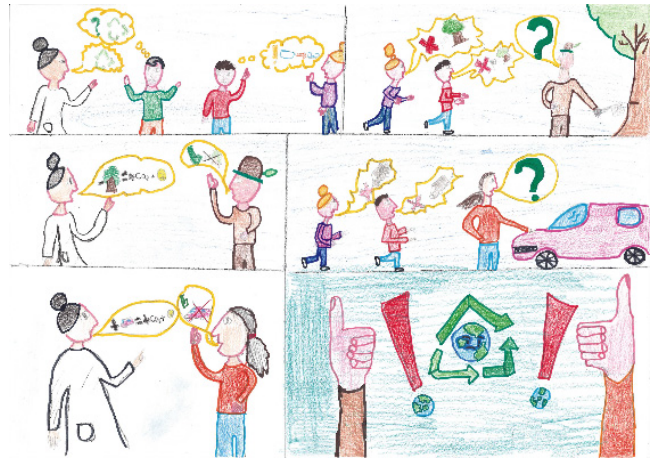

(a)

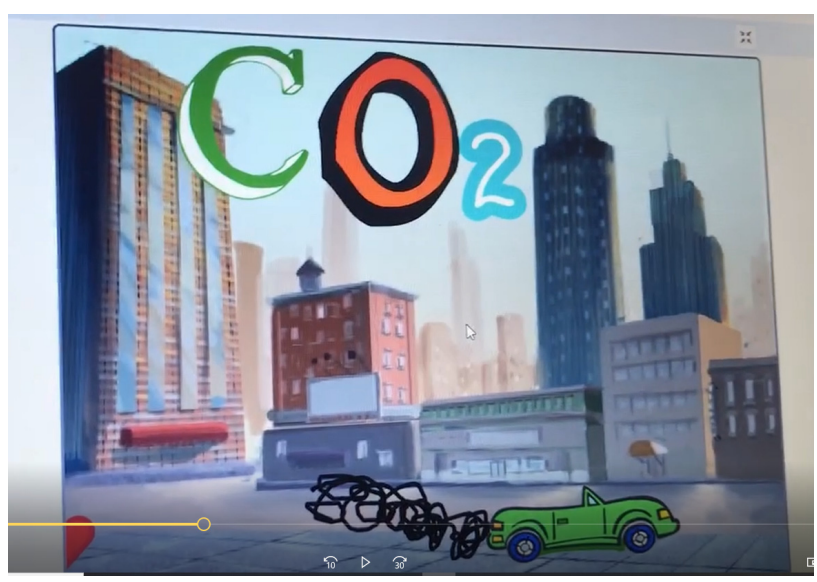

(b)

Figure 2. Example of stories created by pupils. The creative components and the communication phase of the learning flow of the project were inspirational and motivating for participating students: (a) storyboard for the story We are ambassadors. [we need urgently to talk to you about climate crisis]; (b) Stop to unnecessary $\mathrm{CO}_{2}$ emission [Yes, it is still possible!]. This video, made with Minecraft, emphasizes what adults should do to cut their carbon emissions.

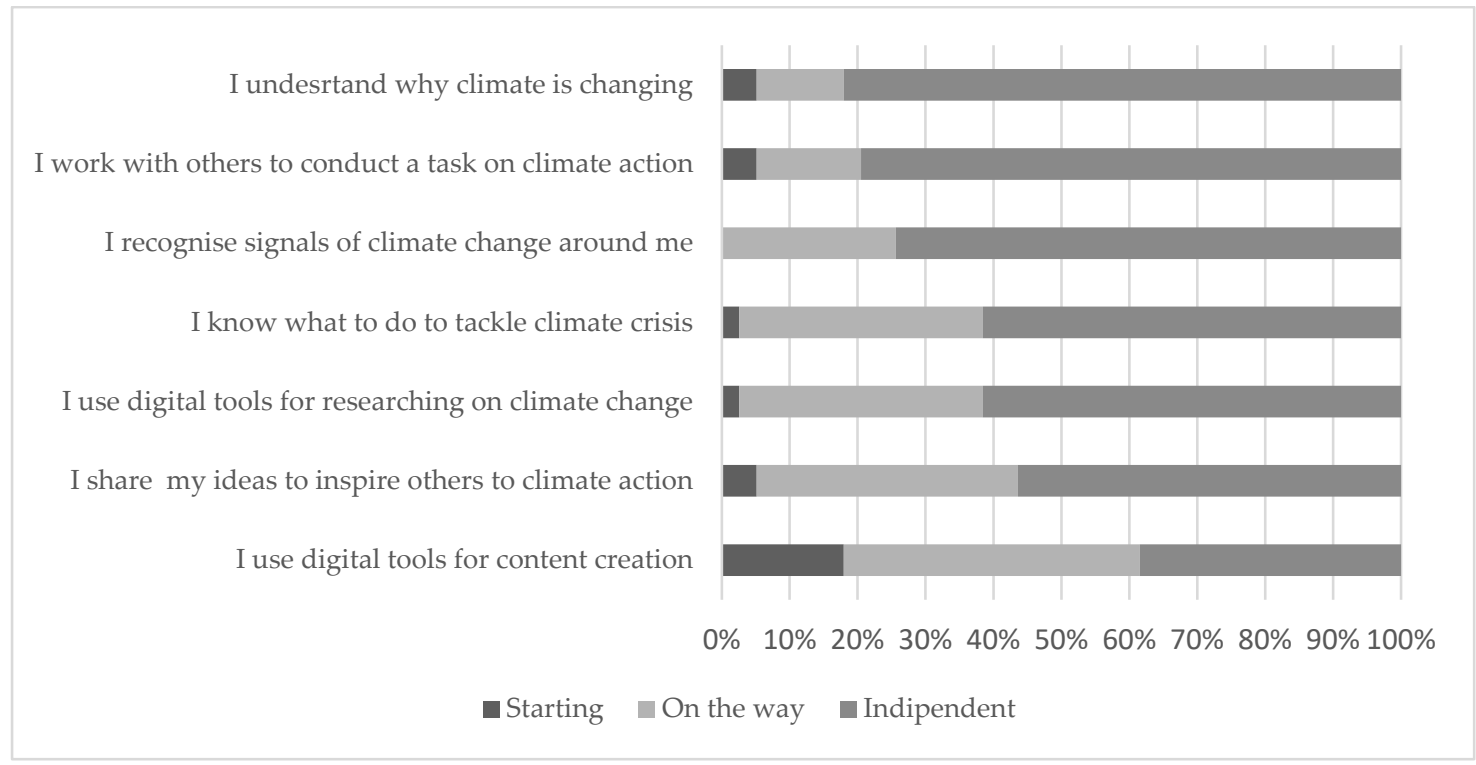

Figure 3. Results from pupils' self-assessment of content knowledge and competences development after completing the piloting.

\section{Conclusions}

The inquiry approach, revised to include an imaginative, creative phase for digital storytelling, was shown to be an access point for engaging in learning, enhancing scientific, digital and climate literacy, persisting in problem-solving and civic action, promoting collaboration and cooperative work between students, teachers and the community. Work on a real-world content, the climate crisis, has also received positive feedback when developed in the curricular disciplines, as it made learning more meaningful and applicable for students, thus influencing their motivation and the possibilities to learn to act for sustainability $[12,13]$. 
Author Contributions: L.B. and D.C. both contributed equally to all aspects of the paper. All authors have read and agreed to the published version of the manuscript.

Funding: This research was developed within the project Change the Story funded by the Erasmus + programme of the EC, grant number 2019-1-UK01-KA201-061432.

Institutional Review Board Statement: Not applicable.

Informed Consent Statement: Informed consent was obtained from all subjects involved in the study. No personal data was collected and all the data was anonymised.

Data Availability Statement: Data are available on request to the corresponding author.

Acknowledgments: The authors acknowledge the work of all the teachers and students who participated in the Italian piloting of the Change the Story project.

Conflicts of Interest: The authors declare no conflict of interest.

\section{References}

1. Rieckmann, M.; Mindt, L.; Gardiner, S. Education for Sustainable Development Goals; Learning objectives; UNESCO: Paris, France, 2017.

2. UNESCO. Shaping the education of tomorrow. In Report on the Un Decade of Education for Sustainable Development; UNESCO: Paris, France, 2012.

3. UNESCO. Roadmap for Implementing the Global Action Programme on Education for Sustainable Development; UNESCO: Paris, France, 2014.

4. Jensen, B.; Schnack, K. The action competence approach in environmental education. Environ. Educ. Res. 1997, 3, 163-178. [CrossRef]

5. Change the Story. Creating New Climate Stories across Europe. Available online: www.changethestory.eu (accessed on 16 December 2021).

6. Feldman, A.; Altrichter, H.; Posch, P.; Somekh, B. Teachers Investigate Their Work. In An Introduction to the Methods of Action Research Across the Professions; Routledge: London, UK, 2007.

7. Bybee, R.; Taylor, J.J.A.; Gardner, A.; Van Scotter, P.; Carlson, J.; Westbrook, A.; Landes, N. The BSCS 5E Instructional Model: Origins and Effectiveness; BSCS: Colorado Springs, CO, USA, 2006.

8. Minner, D.D.; Levy, A.J.; Century, J. Inquiry-based science instruction-What is it and does it matter? Results from a research synthesis years 1984 to 2002. J. Res. Sci. Teach. 2010, 47, 474-496. [CrossRef]

9. Smith, G.; Sobel, D. Place- and Community-Based Education in Schools; Routledge, Taylor \& Francis Group: Abingdon, UK, 2010.

10. Boy, A.G. From STEM to STEAM: Toward a human-centred education, creativity \& learning thinking. In Proceedings of the 31st European Conference on Cognitive Ergonomics (ECCE'13), Toulouse, France, 26-28 August 2013; Association for Computing Machinery: New York, NY, USA; Article 3, pp. 1-7. [CrossRef]

11. Mishra, P.; Koehler, M.J. Technological Pedagogical Content Knowledge: A Framework for Teacher Knowledge. Teach. Coll. Rec. 2006, 108, 1017-1054. [CrossRef]

12. Læssøe, J. Education for sustainable development, participation and socio-cultural change. Environ. Educ. Res. 2010, 16, 39-57. [CrossRef]

13. Mogensen, F.; Schnack, K. The action competence approach and the "new" discourses of education for sustainable development, competence and quality criteria. Environ. Educ. Res. 2010, 16, 59-74. [CrossRef] 